\title{
In vivo, intrinsic kinematics of the foot and ankle
}

\author{
Toni Arndt ${ }^{1,2^{*}}$, Chris Nester ${ }^{3}$, Paul Lundgren ${ }^{1}$, Arne Lundberg ${ }^{1}$, Peter Wolf ${ }^{4}$ \\ From 3rd Congress of the International Foot and Ankle Biomechanics Community \\ Sydney, Australia. 11-13 April 2012
}

\section{Background}

There are obvious problems involved in the accurate description of movement of the intrinsic bones within the foot and ankle. The 26 small bones are difficult, if not impossible to individually represent with standard skin mounted markers for motion analysis [1,2]. This international research collaboration has performed a number of studies in which invasively inserted intracortical pins are used for anchoring reflective markers, thereby providing a direct representation of the kinematics of the individual segments.

\section{Materials and methods}

A number of experimental sessions have been performed at Karolinska Institute. The intracortical pins were inserted by experienced orthopaedic surgeons under sterile conditions and using local anaesthetics (Figure 1). Triads of reflective markers were attached to the protruding ends of the pins and standard video based motion analysis (Qualysis, Sweden) conducted. Data have been published concerning walking [3] and slow running [4] and more recent work has for the first time investigated applied scientific questions such as the effect of shoe manipulations and in-shoe orthotics.

Table 1 Mean total ranges of motion (ROM) and standard deviations of motion about selected joints in the sagittal, frontal and transverse planes during walking. Data from six healthy, male subjects. From Lundgren et al., 2008.

\begin{tabular}{|c|c|c|c|c|c|c|c|c|c|c|}
\hline \multirow[t]{2}{*}{ plane } & \multicolumn{2}{|c|}{ calc-tib } & \multicolumn{2}{|c|}{ calc-tal } & \multicolumn{2}{|c|}{ nav-tal } & \multicolumn{2}{|c|}{ cub-calc } & \multicolumn{2}{|c|}{ cub-nav } \\
\hline & $\begin{array}{c}\mathrm{ROM} \\
{\left[^{\circ}\right]}\end{array}$ & SD & $\begin{array}{c}\mathrm{ROM} \\
{\left[^{\circ}\right]}\end{array}$ & SD & $\begin{array}{c}\mathrm{ROM} \\
{\left[^{\circ}\right]}\end{array}$ & $\mathrm{SD}$ & $\begin{array}{c}\mathrm{ROM} \\
{\left[^{\circ}\right]}\end{array}$ & SD & $\begin{array}{c}\mathrm{ROM} \\
{\left[^{\circ}\right]}\end{array}$ & $\overline{\mathrm{SD}}$ \\
\hline & 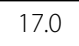 & 2. & 6.8 & 1.4 & 8.4 & 1 & 9.7 & 5.2 & 2 & $2 .{ }^{2}$ \\
\hline & 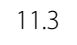 & 3.5 & 9.8 & 1.8 & 14.9 & 6.1 & 11 & 3 & 8.8 & 4.4 \\
\hline 115 & .3 & 2.4 & 7.5 & 2.0 & 16.3 & 6.5 & 8.1 & 2.0 & 8.9 & 4.3 \\
\hline
\end{tabular}
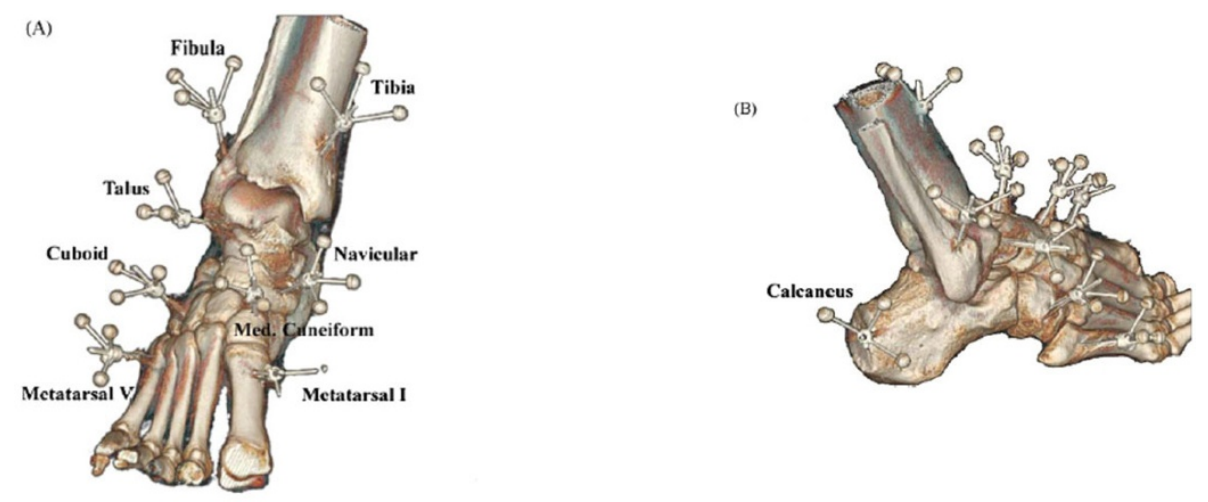

Figure 1 Computer tomography images of the marker locations on intracortical pins in foot and ankle segments.

* Correspondence: toni.arndt@ki.se

'Karolinska Institute, Stockholm, 14186, Sweden

Full list of author information is available at the end of the article 


\section{Results}

\section{Conclusions}

A large range of fundamental data concerning foot and ankle kinematics during walking and running and with various manipulations have been collected and will be presented.

\section{Author details}

'Karolinska Institute, Stockholm, 14186, Sweden. ${ }^{2}$ The Swedish School of Sport and Health Sciences, Stockholm, 11486, Sweden. ${ }^{3}$ University of Salford, Salford, M6 6PU, UK. ${ }^{4}$ ETH Zurich, 8092, Switzerland.

Published: 10 April 2012

\section{References}

1. Nester $C$, et al: Foot kinematics during walking measured using bone and surface mounted markers. J Biomech 2007, 40:3412-3423.

2. Westblad P, et al: Differences in Ankle-Joint Complex Motion during the Stance Phase of Walking as measured by Superficial or Bone anchored Markers. Foot Ankle Int 2002, 23:856-863.

3. Lundgren $P$, et al: Invasive, in vivo measurement of rear, mid and forefoot motion during walking. Gait Posture 2008, 28:93-100.

4. Arndt A, et al: Intrinsic foot kinematics measured in vivo during the stance phase of slow running. J Biomech 2007, 40:2672-2678.

doi:10.1186/1757-1146-5-S1-K5

Cite this article as: Arndt et al.: In vivo, intrinsic kinematics of the foot and ankle. Journal of Foot and Ankle Research 2012 5(Suppl 1):K5.

\section{Submit your next manuscript to BioMed Central} and take full advantage of:

- Convenient online submission

- Thorough peer review

- No space constraints or color figure charges

- Immediate publication on acceptance

- Inclusion in PubMed, CAS, Scopus and Google Scholar

- Research which is freely available for redistribution

Submit your manuscript at www.biomedcentral.com/submit
Ciomed Central 